\title{
GAMBARAN BIAYA PADA PASIEN UMUM DEMAM TIFOID ANAK DI INSTALASI RAWAT INAP RSUD WANGAYA PERIODE 2015
}

\section{(ANALYSIS OF THE COSTS INPATIENTS COMMON TYPHOID FEVER CHILD IN INPATIENT INSTALLATION RSUD WANGAYA THE PERIOD 2015)}

\author{
FITRIA MEGAWATI ${ }^{1}$, I PUTU TANGKAS SUWANTARA ${ }^{1}$, I G.A.A. KUSUMA WARDANI ${ }^{1}$ \\ ${ }^{1}$ Akademi Farmasi Saraswati Denpasar, Jalan Kamboja No.11A, Denpasar, Bali
}

\begin{abstract}
Abstrak: Demam tifoid adalah penyakit infeksi akut yang sering ditemukan pada masyarakat di Indonesia, mulai dari usia balita, anak-anak dan dewasa. Anak merupakan individu yang berada dalam satu rentang perubahan perkembangan yang dimulai dari bayi hingga remaja. Tujuan dari penelitian adalah untuk mengetahui rata-rata Biaya pada Pasien Umum Demam Tifoid Anak di Instalasi Rawat Inap RSUD Wangaya periode 2015 serta untuk mengetahui faktor yang mempengaruhi Analisis Biaya pada Pasien Umum Demam Tifoid Anak di Instalasi Rawat Inap RSUD Wangaya periode 2015. Penelitian ini dikerjakan mengikuti rancangan deskriptif analitik, data dikumpulkan secara retrospektif dengan teknik pengambilan sampel purposive sampling dan dilanjutkan dengan menggunakan metode normalitas karena data terdistribusi normal atau homogen maka digunakan uji Descriptive dan uji Correlations. Penelitian dilakukan di Instalasi Rawat Inap Rumah Sakit Umum Daerah Wangaya Denpasar untuk pasien umum demam tifoid anak pada periode 2015. Data yang didapat dari rekam medis akan dianalisis dan dilihat data pasien dan pengobatan yang dilakukan. Untuk mendapatkan hasil yang diinginkan dari karakteristik pasien, karakteristik pengobatan pasien dan karakteristik biaya yang dikeluarkan oleh pasien. Hasil penelitian dari 38 pasien peserta umum dilihat dari karakteristik pasien dan dari segi jenis kelamin yang banyak menderita demam tifoid jenis kelamin perempuan sebesar 25 pasien (66\%), karakteristik pengobatan yaitu obat yang terbanyak Ceftriaxone injeksi sebesar 71 vial (16,2\%), dan karakteristik biaya yang terbanyak yaitu pada kelas II sebesar 21 pasien (55,3\%). Faktor yang mempengaruhi biaya pengobatan pada pasien demam tifoid yaitu umur, kelas perawatan, dan LOS (Length of Stay).
\end{abstract}

Kata kunci: demam tifoid, analisis biaya, jaminan umum.

\begin{abstract}
Typhoid fever is an acute infectious disease that is often found in people in Indonesia, ranging in age from toddlers, children and adults. Children are the individuals who are in a range of developmental changes starting from infants to teenagers. The aim of the study is to determine the average cost at the Public Patients with Typhoid Fever Kids in Hospital Inpatient RSUD Wangaya period for 2015 and to determine the factors that affect the Cost Analysis in Patients with Typhoid Fever General Children Hospital Inpatient RSUD Wangaya 2015 period. This study was undertaken following the descriptive analytic design, the data collected retrospective with technique purposive sampling technique and continued by using the method of normality for normally distributed data or homogeneous then used Descriptve test and test Correlations. The study was conducted in the Inpatient Hospital Regional General Wangaya Denpasar for general patients with typhoid fever children in the period of 2015. The data obtained from the medical records will be analyzed and the views of patient data and treatment performed. To get the desired results from the characteristics of the patient, the patient's characteristics and the characteristics of the treatment costsissued by the patient. The results of the study of 38 patients seen from the general participant characteristics of the patient and ofIn terms of gender that many suffered from typhoid fever female gender by 25 patients $(66 \%)$, the characteristics of drug treatment that is most Ceftriaxone injection vial of $71(16.2 \%)$, and the characteristics of the highest costs are in class II with 21 patients (55.3\%). Factors affecting the cost of treatment in patients with typhoid fever are aged, nursing class, and LOS (Length of Stay).
\end{abstract}

Keywords: typhoid fever, cost analysis, general collateral.

\section{PENDAHULUAN}

Farmakoekonomi adalah ilmu yang mengukur biaya dan hasil yang diperoleh dihubungkan dengan penggunaan obat dalam perawatan kesehatan. Tujuan farmakoekonomi adalah membandingkan obat yang berbeda dengan untuk pengobatan pada kondisi yang sama. Selain itu juga membandingkan

\footnotetext{
•email korespondensi: f.mega83@gmail.com
} 
pengobatan yang berbeda pada kondisi yang berbeda (Vogenberg, 2001). Dimana hasilnya bisa dijadikan informasi yang dapat membantu para pembuat kebijakan dalam menentukan pilihan atas alternatifalternatif pengobatan yang tersedia agar pelayanan kesehatan menjadi lebih efisien dan ekonomis. Informasi farmakoekonomi saat ini dianggap sama pentingnya dengan informasi khasiat dan keamanan obat dalam menentukan pilihan obat mana yang akan digunakan.

Metode Analisa Farmakoekonomi dipisahkan menjadi dua bagian yang berbeda, yaitu: teknik evaluasi ekonomi dan kemanusiaan. Metode ini telah digunakan dalam berbagai bidang dan sedang diterapkan untuk system kesehatan. Teknik evaluasi ekonomi yang digunakan ada empat metode, yaitu: Cost Benefit Analysis (CBA), Cost Effectiveness Analysis (CEA), Cost Minimization Analysis (CMA), dan Cost Utility Analysis (CUA) (Trask, 2011).

Anak merupakan individu yang berada dalam satu rentang perubahan perkembangan yang dimulai dari bayi hingga remaja. Masa anak merupakan masa pertumbuhan dan perkembangan yang dimulai dari bayi (0-1 tahun) usia bermain/oddler (1-2,5 tahun), pra sekolah (2,5-5), usia sekolah (5-11 tahun) hingga remaja (11-18 tahun). Rentang ini berada antara anak satu dengan yang lain mengingat latar belakang anak berbeda. Pada anak terdapat rentang perubahan pertumbuhan dan perkembangan yaitu rentang cepat dan lambat.

Demam tifoid (typhoid fever) adalah penyakit infeksi akut yang biasanya mengenai saluran cerna dengan gejala demam lebih dari satu minggu dan terdapat gangguan kesadaran (Mansjoer dkk, 2000). Badan Kesehatan Dunia (WHO) memperkirakan jumlah kasus demam tifoid di seluruh dunia mencapai 16-33 juta dengan 500-600 ribu kematian tiap tahunnya.

Rumah Sakit Umum Daerah Wangaya adalah salah satu rumah sakit milik pemerintah yang melayani penggunaan BPJS kesehatan dan diharapkan dapat memberikan pelayanan yang terbaik.

Adapun tujuan dari penelitian adalah untuk mengetahui rata-rata Biaya pada Pasien Umum Demam Tifoid Anak di Instalasi Rawat Inap RSUD Wangaya periode 2015 dan faktor yang mempengaruhi Analisis Biaya pada Pasien Umum Demam Tifoid Anakdi Instalasi Rawat Inap RSUD Wangaya periode 2015. Adapun rumusan masalah dalam penelitian ini adalah sebagai berikut

1. Bagaimana rata-rata Biaya Pengobatan pada Pasien Umum Demam Tifoid Anak di Instalasi Rawat Inap RSUD Wangaya periode 2015.
2. Bagaimana faktor yang mempengaruhi Analisis Biaya pada Pasien Umum Demam Tifoid Anak di Instalasi Rawat Inap RSUD Wangaya periode 2015.

\section{METODE PENELITIAN}

Penelitian ini dilakukan di Bagian Rekam Medik, Gudang Medik dan Bagian Keuangan di RSUD Wangaya Denpasar. Waktu penelitian dilakukan pada bulan April sampai bulan Juni dengan mengambil data Rekam Medik dan bagian keuangan tentang Analisis Biaya Pada Penderita Demam Tifoid Anak.

Penelitian ini merupakan jenis penelitian deskriptif yaitu penelitian yang diarahkan untuk mendeskripsikan atau menguraikan suatu keadaan di dalam suatu komunitas atau masyarakat. Pelaksanaan pengambilan data secara retrospektif yang didasarkan pada catatan Rekam Medik dan bagian Keuangan di Rumah Sakit Umum Daerah Wangaya Denpasar.

Populasi penelitian adalah seluruh pasien anak dengan diagnosa demam tifoid yang menjalani rawat inap di RSUD Wangaya Denpasar pada periode 2015.

Sampel penelitian yaitu:

A. Kriteria Inklusi :

1. Pasien anak yang dirawat inap dengan diagnosis demam tifoid yang mendapatkan terapi pengobatan.

2. Pasien demam tifoid anak yang mempunyai rekam medik dan data dibagian keuangan.

B. Kriteria Eksklusi :

1. Pasien yang dirawat inap dengan diagnosis demam tifoid anak dan tidak mendapatkan terapi pengobatan.

2. Pasien demam tifoid yang pulang paksa.

3. Data tidak lengkap.

Variabel penelitian ialah segala sesuatu yang akan menjadi objek pengamatan penelitan. Variabel yang digunakan adalah sebagai berikut:

1. Jenis Kelamin

2. Umur

3. Kelas Perawatan

4. Lama Perawatan

5. Tanggal masuk dan tanggal keluar dari Rumah

Sakit Wangaya

6. Jenis Obat yang digunakan

7. Jenis Alat Kesehatan yang digunakan

Teknik pengumpulan data pada penelitian ini adalah teknik purposive sampling yaitu dengan menggunakan data yang diambil dari data rekam medis Pada Pasien Umum Demam Tifoid Anak di Rumah Sakit Umum Daerah Wangaya Denpasar. 
Alur kerja pengumpulan data pada penelitian ini adalah:

1. Melakukan studi pendahuluan dengan mencari data 10 penyakit terbanyak tahun 2015 dibagian rekam medik RSUD Wangaya Denpasar.

2. Penyusunan Proposal.

3. Pembuatan surat rekomendasi ijin penelitian dari kampus.

4. Pengajuan ijin penelitian di RSUD Wangaya Denpasar.

5. Mencari data dan biaya pasien umum demam tifoid anak dibagian rekam medis dan bagian Keuangan di RSUD Wangaya Denpasar.

6. Data yang dikumpulkan berupa data sekunder dari berbagai sumber, yaitu dari Rekam Medis pasien yang diteliti, Gudang Medis dan pada Bagian Keuangan.

7. Data yang telah terkumpul diperiksa terlebih dahulu dan dilakukan proses editing atau penyuntingan data.

8. Hal ini perlu dilakukan untuk mengetahui apakah data yang telah diperoleh sesuai dengan data yang diperlukan dalam penelitian. Data dianalisis secara deskriptif. ACER (average cost effectiveness ratio) adalah metode yang digunakan untuk menganalisis efektivitas biaya dan menghitung besar biaya yang harus dikeluarkan, dihitung berdasarkan jumlah biaya antibiotik yang dikeluarkan dibagi dengan efektivitas (lama pasien dirawat).

Tabel. 1 Rumus ACER

$\mathrm{ACER}=$ health care cost $(\mathrm{RP}) /$ clinical
outcame $($ biaya perawatan $)$

\section{HASIL DAN PEMBAHASAN}

Dari data yang diperoleh melalui rekam medis Rumah Sakit Umum Daerah Wangaya Denpasar Periode 2015, didapatkan sampel pasien umum demam tifoid anak sebanyak 38 pasien pada periode 2015 yang memenuhi kriteria inklusi.

\section{Karakateristik Pasien Umum Demam Tifoid Anak di RSUD WANGAYA}

Persentase jumlah subjek berdasarkan umur, jenis kelamin, kelas perawatan dan lama rawat inap pada pasien demam tifoid anak di Rumah Sakit Umum Daerah Wangaya Denpasar Periode 2015 dapat dilihat dari tabel berikut:
Tabel. 2 Karakteristik Pasien Umum Demam Tifoid Anak

\begin{tabular}{cccc}
\hline \multicolumn{2}{c}{ Karakteristik Pasien } & Jumlah & $\begin{array}{c}\text { Persentase } \\
(\%)\end{array}$ \\
\hline $\begin{array}{c}\text { Umur } \\
\text { (tahun) }\end{array}$ & 5-7 tahun & 22 Orang & $57,9 \%$ \\
Jenis & L-11 tahun & 16 Orang & $42,1 \%$ \\
Kelamin & Perempuan & 25 Orang & $66,0 \%$ \\
& VIP (UtamaAmerta) & 7 Orang & $18,5 \%$ \\
Kelas & Kelas I (Kaswari) & 6 Orang & $15,7 \%$ \\
Perawatan & Kelas II (Kaswari) & 21 Orang & $55,3 \%$ \\
& Kelas III (Kaswari) & 4 Orang & $10,5 \%$ \\
& 3 hari & 10 Orang & $26,0 \%$ \\
LOS & 4 hari & 12 Orang & $31,0 \%$ \\
(hari) & 5 hari & 10 Orang & $26,0 \%$ \\
& 6 hari & 6 Orang & $15,0 \%$ \\
\hline
\end{tabular}

\section{Karakteristik Pengobatan Pasien Umum Demam Tifoid Anak di RSUD Wangaya}

Dari penelitian pasien umum demam tifoid anak di RSUD Wangaya Denpasar yang didapatkan hasil berdasarkan karakteristik pengobatan pasien demam tifoid yang dilihat dari 10 besar penggunaan obat dan alat kesehatan yang paling sering digunakan pada pasien demam tifoid di RSUD Wangaya.

Tabel. 3 Sepuluh Besar Penggunaan Obat Pada Pasien Demam Tifoid

\begin{tabular}{clcc}
\hline No & \multicolumn{1}{c}{ Obat } & Jumlah & $\begin{array}{c}\text { Persentase } \\
(\mathbf{\%})\end{array}$ \\
\hline $\mathbf{1}$ & Ceftriaxon & 71 Vial & $16,2 \%$ \\
$\mathbf{2}$ & Dextrose 5\% Infus & 65 Fles & $14,8 \%$ \\
$\mathbf{3}$ & RL Wida OGB 500ml & 63 Botol & $14,4 \%$ \\
$\mathbf{4}$ & Ranitidine Injeksi & 47 Ampul & $10,7 \%$ \\
$\mathbf{5}$ & L-bio & 44 Sachet & $10,3 \%$ \\
$\mathbf{6}$ & Sanmol Tablet & 43 Tablet & $9.8 \%$ \\
$\mathbf{7}$ & Ecosol RL OGB & 30 Fles & $6,8 \%$ \\
$\mathbf{8}$ & Cefixime Capsule & 30 Capsule & $6,8 \%$ \\
$\mathbf{9}$ & Otsu Water Injeksi 25ml & 25 Fles & $5.7 \%$ \\
$\mathbf{1 0}$ & Dexametasone Injeksi & 20 Ampul & $4,5 \%$ \\
& Jumlah & 438 & $100,0 \%$ \\
\hline
\end{tabular}

Tabel. 4 Sepuluh Besar Penggunaan Alat Kesehatan Pada Pasien Demam Tifoid

\begin{tabular}{cccc}
\hline No & Alat Kesehatan & Jumlah & $\begin{array}{c}\text { Persentase } \\
(\%)\end{array}$ \\
\hline $\mathbf{1}$ & Hypafix 20cm x 5cm & $120 \mathrm{Rol}$ & $27,0 \%$ \\
$\mathbf{2}$ & Spuit 3cc Strea & $109 \mathrm{Biji}$ & $24,6 \%$ \\
$\mathbf{3}$ & Spuit 5cc Strea & $73 \mathrm{Biji}$ & $16,6 \%$ \\
$\mathbf{4}$ & Spuit 10cc Nipro & $34 \mathrm{Biji}$ & $7,7 \%$ \\
$\mathbf{5}$ & Spuit 3cc Nipro & $31 \mathrm{Biji}$ & $6,9 \%$ \\
$\mathbf{6}$ & Introcan Safety G 22 & $23 \mathrm{Biji}$ & $5,3 \%$ \\
$\mathbf{7}$ & Spuit 5cc Nipro & $20 \mathrm{Biji}$ & $4,5 \%$ \\
$\mathbf{8}$ & Intrafix Safeset Is & $14 \mathrm{Biji}$ & $3,2 \%$ \\
$\mathbf{9}$ & Tegaderm & $11 \mathrm{Biji}$ & $2,4 \%$ \\
$\mathbf{1 0}$ & Elastomul 8cm x 4cm & $8 \mathrm{Rol}$ & $1,8 \%$ \\
& Jumlah & 443 & $100,0 \%$ \\
\hline
\end{tabular}




\section{Komponen Biaya pada Pasien Umum Demam Tifoid Anak di RSUD Wangaya}

Dari penelitian Pasien Umum Demam Tifoid Anak di RSUD Wangaya yang didapatkan hasil berdasarkan komponen Biaya Pada Pasien Umum Demam Tifoid di masing-masing kelas perawatan Rumah Sakit Umum Daerah Wangaya Denpasar periode 2015 dapat dilihat dari tabel berikut :

Tabel. 5 Biaya Pengobatan Pasien Umum Demam Tifoid Anak

\begin{tabular}{|c|c|c|c|c|c|}
\hline No & $\begin{array}{c}\text { Komponen } \\
\text { Biaya }\end{array}$ & $\underset{(\mathbf{R p})}{\text { Minimal }}$ & $\begin{array}{l}\text { Maksimal } \\
\text { (Rp) }\end{array}$ & $\begin{array}{l}\text { Rata-rata } \\
\text { (Rp) }\end{array}$ & $\begin{array}{c}\% \\
\text { dari } \\
\text { biaya } \\
\text { total }\end{array}$ \\
\hline \multirow{5}{*}{1} & \multicolumn{5}{|c|}{ VIP (UTAMA AMERTA) } \\
\hline & $\begin{array}{l}\text { Biaya } \\
\text { Perawatan }\end{array}$ & $125.000,00$ & $920.000,00$ & $174.166,66$ & $17,3 \%$ \\
\hline & $\begin{array}{l}\text { Biaya } \\
\text { Farmasi }\end{array}$ & $100.587,50$ & $1.527 .512,00$ & $271.349,33$ & $26,8 \%$ \\
\hline & $\begin{array}{l}\text { Biaya Sewa } \\
\text { Kamar }\end{array}$ & $865.000,00$ & $2.240 .000,00$ & $517.500,00$ & $51,0 \%$ \\
\hline & $\begin{array}{l}\text { Biaya } \\
\text { Laboraturium }\end{array}$ & $37.000,00$ & $266.000,00$ & $50.500,00$ & $4,9 \%$ \\
\hline \multirow{5}{*}{2} & \multicolumn{5}{|c|}{ Kelas I (KASWARI) } \\
\hline & $\begin{array}{l}\text { Biaya } \\
\text { Perawatan }\end{array}$ & $165.000,00$ & $930.000,00$ & $182.500,00$ & $19,5 \%$ \\
\hline & $\begin{array}{l}\text { Biaya } \\
\text { Farmasi }\end{array}$ & $10.250,00$ & $1.233 .393,75$ & $207.398,83$ & $22,3 \%$ \\
\hline & $\begin{array}{l}\text { Biaya Sewa } \\
\text { Kamar }\end{array}$ & $427.500,00$ & $1.237 .500,00$ & $277.500,00$ & $29,7 \%$ \\
\hline & $\begin{array}{l}\text { Biaya } \\
\text { Laboraturium }\end{array}$ & 132.000 .00 & $1.464 .000,00$ & $266.000,00$ & $28,5 \%$ \\
\hline \multirow{5}{*}{3} & \multicolumn{5}{|c|}{ Kelas II (KASWARI) } \\
\hline & $\begin{array}{l}\text { Biaya } \\
\text { Perawatan }\end{array}$ & $103.000,00$ & $703.000,00$ & $47.411,76$ & $23,8 \%$ \\
\hline & $\begin{array}{l}\text { Biaya } \\
\text { Farmasi }\end{array}$ & $53.828,75$ & $936.598,70$ & $58.260,43$ & $29,3 \%$ \\
\hline & $\begin{array}{l}\text { Biaya Sewa } \\
\text { Kamar }\end{array}$ & $230.000,00$ & $910.000,00$ & $67.058,82$ & $33,7 \%$ \\
\hline & $\begin{array}{l}\text { Biaya } \\
\text { Laboraturium }\end{array}$ & $48.000,00$ & $396.000,00$ & $26.117,64$ & $13,2 \%$ \\
\hline \multirow{5}{*}{4} & \multicolumn{5}{|c|}{ Kelas III (KASWARI) } \\
\hline & $\begin{array}{l}\text { Biaya } \\
\text { Perawatan }\end{array}$ & $120.000,00$ & $1.156 .196,00$ & $319.049,00$ & $34,5 \%$ \\
\hline & $\begin{array}{l}\text { Biaya } \\
\text { Farmasi }\end{array}$ & $118.180,00$ & $1.130 .239,90$ & $312.118,47$ & $33,8 \%$ \\
\hline & $\begin{array}{l}\text { Biaya Sewa } \\
\text { Kamar }\end{array}$ & $270.000,00$ & $428.000,00$ & $147.500,00$ & $18,8 \%$ \\
\hline & $\begin{array}{l}\text { Biaya } \\
\text { Laboraturium }\end{array}$ & $206.000,00$ & $271.390,00$ & $119.347,50$ & $12,9 \%$ \\
\hline
\end{tabular}

Faktor yang mempengaruhi Total Biaya Pasien Umum Demam Tifoid Anak

Dari penelitian pasien demam tifoid peserta umum di RSUD Wangaya Denpasar didapatkan faktor yang mempengaruhi total biaya pengobatan pasien demam tifoid di Rumah Sakit Umum Daerah Wangaya periode tahun 2015.

Tabel. 6 Faktor yang mempengaruhi total biaya pengobatan pasien demam tifoid

\begin{tabular}{llcl}
\hline No & \multicolumn{1}{c}{ Kategori } & P & \multicolumn{1}{c}{ Keterangan } \\
\hline $\mathbf{1}$ & Umur & 0.011 & Berkolerasi secara singifikan \\
\hline $\mathbf{2}$ & Kelas perawatan & 0.032 & Berkolerasi secara singifikan \\
\hline $\mathbf{3}$ & Lama Dirawat & 0.129 & $\begin{array}{l}\text { Tidak berkolerasi secara } \\
\text { signifikan }\end{array}$ \\
\hline $\mathbf{4}$ & Jumlah Antibiotik & 0.251 & $\begin{array}{l}\text { Tidak berkolerasi secara } \\
\text { signifikan }\end{array}$ \\
\hline
\end{tabular}

\section{Karakateristik Pasien Demam Tifoid}

Penelitian ini dilakukan bertujuan untuk mengetahui jumlah pasien demam tifoid yang dilihat dari karakteristik pasien meliputi jenis kelamin, umur, kelas perawatan dan lama rawat inap, mengetahui obat-obat yang sering digunkan pada pengobatan demam tifoid serta mengetahui kerasionalan biaya pengobatan demam tifoid. Penelitian dilakukan dengan mengambil sampel data rekam medis pasien rawat inap dari instalasi Rumah Sakit Umum Daerah Wangaya Denpasar. Pengambilan sampel pasien diambil dari data rekam medis dan data pasien yang terdiagnosa demam tifoid yaitu sebanyak 38 pasien.

Berdasarkan hasil tabel observasi pasien yang dilihat dari umur pasien, usia 5-7 tahun sebanyak 22 orang $(57,9 \%)$, usia 8-11 tahun sebanyak 16 orang $(42,1 \%)$. Dari hasil tersebut dapat dilihat bahwa pada usia 5-7 tahun adalah jumlah yang paling banyak dibandingkan usia 8-11 tahun, hal ini dapat disebabkan karena usia anak-anak sekolah biasanya membeli makanan dan minuman sembarangan dan tidak terjamin kebersihannya. Dan lingkungan tempat yang paling berperan penting dalam penyebaran kuman Salmonella Typhi.

Berdasarkan karakteristik pasien yang dilihat dari jenis kelamin, pasien demam tifoid paling banyak diderita pada pasien berjenis kelamin perempuan yaitu sebanyak 25 pasien (65\%) sedangkan laki-laki 13 pasien (34\%). Penyakit demam tifoid dapat dialami siapa saja dan tidak ada perbedaan jenis kelamin laki-laki atau perempuan, tetapi umumnya penyakit demam tifoid sering diderita oleh anak-anak. (Raflizar, 2006).

Berdasarkan hasil obervasi pasien yang dilihat dari kelas perawatan yaitu pasien paling banyak menginap di kelas II (Kaswari) sebanyak 21 pasien (57\%), hal ini dikarenakan biaya perawatan kelas II (Kaswari) lebih terjangkau dan nyaman. Walaupun masih ada perawatan kelas III yang lebih murah akan tetapi pola berpikir masyarakat cenderung memandang kelas III terlalu jelek pelayanan dan fasilitasnya. Sedangkan VIP dan kelas I dianggap terlalu mahal sehingga sebagian besar memilih cukup dirawat dikelas II.

Berdasarkan hasil observasi pasien yang dilihat dari lama rawat inap (LOS), diantara pasien demam tifoid yang paling banyak dengan lama rawat inap yaitu 4 hari sebanyak 12 pasien (31\%), hal ini disebabkan karena obat yang dikonsumsi dapat menyebabkan daya tahan tubuh menjadi meningkat. Lama rawat inap pasien dapat dipengaruhi oleh beberapa faktor seperti tingkat keparahan penyakit, efek samping obat dan kemungkinan pasien sudah menkonsumsi obat sebelum masuk rumah sakit. Lama rawat pasien juga dapat mempengaruhi 
besarnya biaya yang dikeluarkan oleh pasien selama menjalani perawatan di rumah sakit (Rima dkk., 2014).

\section{Karakteristik Pengobatan pada Pasien Umum Demam Tifoid Anak}

Berdasarkan hasil observasi pasien yang dilihat dari karakteristik pengobatan pada pasien demam tifoid yang dilihat dari frekuensi 10 besar pengobatan pada pasien demam tifoid di RSUD Wangaya Denpasar. Yang paling banyak yaitu ceftriaxon sebanyak 71 vial $(16,2 \%)$. Hal ini dikarenakan Ceftriaxon merupakan antibiotik yang mampu membunuh kuman Salmonella Thypi. Antibiotik ini sangat cocok diberikan pada pasien demam tifoid anak dikarenakan tidak ada efek samping yang membahayakan untuk anak. Berdasarkan hasil penelitian demam tifoid rawat inap di RSUD Wangaya Denpasar periode 2015 bahwa antibiotik yang banyak digunakan adalah Ceftriaxon injeksi sebanyak 71 vial, terbanyak kedua yang digunakan adalah Cefixime capsul yang diberikan sebagai pengobatan tambahan setelah pasien selesai dirawat inap di rumah sakit.

Berdasarkan hasil penelitian demam tifoid rawat inap di Rumah Sakit Umum Daerah Wangaya Denpasar Periode 2015 menyatakan bahwa Ceftriaxon merupakan jenis antibiotik pilihan terbanyak yang digunakan untuk pasien demam tifoid kemudian Cefixime merupakan antibiotik pilihan kedua yang banyak digunakan. Hal ini disebabkan karena harga obat sediaan tablet dengan injeksi berbeda, sediaan injeksi paling banyak digunakan saat pasien di rawat inap sedangkan tablet kebanyakan digunakan untuk pengobatan tambahan saat pasien selesai rawat inap.

Berdasarkan hasil observasi pasien yang dilihat dari karakteristik pengobatan pada pasien demam tifoid dari frekuensi 10 besar alkes pada pasien demam tifoid yang paling banyak adalah spuit seperti spuit 3cc. Hal ini disebabkan karena pada pengobatan untuk rawat inap pasien sebagian besar mendapatkan jenis sediaan injeksi. Sedangkan alkes terbanyak kedua yang digunakan adalah Hypafix $20 \mathrm{~cm} \times 5 \mathrm{~cm}$ yang banyak digunakan untuk merekatkan infus pada pasien anak agar tidak mudah lepas.

\section{Komponen Biaya pada Pasien Umum Demam Tifoid Anak}

Penelitian ini dilakukan bertujuan untuk mengetahui jumlah biaya pengobatan pasien demam tifoid yang dilihat dari karakteristik biaya pada pasien demam tifoid meliputi biaya perawatan, biaya farmasi, biaya sewa kamar dan biaya laboraturium dari masing-masing kelas perawatan pasien. Serta membandingan biaya pengobatan dari masing kelas perawatan. Penelitian dilakukan dengan mengambil sampel data rekam medis pasien rawat inap dari instalasi Rumah sakit. Pengambilan sampel pasien diambil dari data rekam medis dan data pasien yang terdiagnosa demam tifoid yaitu sebanyak 38 pasien.

Berdasarkan data yang didapatkan dari hasil observasi pasien yang dilihat dari kelas perwatan dibagi menjadi 4 kelas perawatan yaitu VIP (Utama Amerta), kelas I (Kaswari), kelas II (Kaswari) dan kelas III (Kaswari). Dari hasil observasi yang diperoleh biaya pengobatan pasien demam tifoid yang paling besar yaitu biaya pengobatan pasien kelas VIP (Utama Amerta), hal ini disebabkan karena biaya perawatan dan biaya sewa kamar yang mahal sehingga memerlukan biaya yang banyak. Namun dilihat dari banyaknya pasien demam tifoid sebagian besar pasien memilih kelas perawatan kelas II, hal ini disebabkan karena biaya perawatan dan biaya sewa kamar kelas II lebih terjangkau pada pengobatan pasien. Untuk biaya farmasi dan biaya laboraturium pada pasien demam tifoid sebagian besar sama. Dari penelitian sebelumnya mengatakan bahwa faktor-faktor yang mempengaruhi biaya total perawatan adalah usia, lama perawatan atau Length of Stay, kelas perawatan dan jenis pelayanan (Ria dkk.,2012).

\section{Faktor Yang Mempengaruhi Total Biaya Pada Pasien Umum Demam Tifoid Anak}

Faktor-faktor yang mempengaruhi besarnya biaya total rawat inap diperoleh dengan cara uji statistik menggunakan metode descriptive dan metode Correlation karena data tersebut masuk dalam katagori normal dan homogenitas. Uji ini dilakukan pada kategori umur, kelas perawatan, LOS dan jumlah antibiotik. Dari hasil tersebut terlihat bahwa nilai $\mathrm{P}<0,005$ adalah pada katagori umur dan LOS yang berarti ada perbedaan dalam biaya total perawatan pada masing-masing kelompok katagori. Dengan demikian faktor-faktor yang mempengaruhi biaya total perawatan adalah umur dan kelas perawatan.

Kelas perawatan menjadi faktor utama yang sangat mempengaruhi biaya perawatan. Kelas perawatan VIP memiliki rata-rata biaya total perawatan paling mahal diantara kelas perawatan yang lainnya dan pelayanan pada VIP sangatlah baik dan nyaman. Hal ini menyebabkan perbedaan pada biaya perawatan, biaya farmasi, biaya sewa kamar, dan biaya laboratorium.

Umur menjadi faktor yang mempengaruhi biaya pengobatan. Karena disebabkan oleh rata-rata biaya obat dan bahan habis pakai sebanding dengan peningkatan usia. Sehingga menyebabkan biaya penggunaan obat dan bahan medis habis pakai sangat besar dan sangat mempengaruhi biaya farmasi. 


\section{KESIMPULAN}

Berdasarkan penelitian yang telah dilakukan dapat disimpulkan bahwa:

1. Rata-rata biaya pengobatan pada kelas perawatan VIP (Utama Amerta) sebanyak Rp 1.013.515. Rata-rata biaya pengobatan pada kelas I (Kaswari) sebanyak Rp 933.398.00. Rata-rata biaya pengobatan pada kelas II (Kaswari) sebanyak Rp189.846.00. Rata-rata biaya pengobatan pada kelas III (Kaswari) sebanyak Rp 898.014.00 dengan nilai Standar Deviasi Rp. $377.833,00$

2. Faktor yang mempengaruhi biaya pengobatan pada pasien demam tifoid yaitu umur, kelas perawatan, dan LOS (Length of Stay).

\section{UCAPAN TERIMAKASIH}

Ucapan terimakasih kepada seluruh pihak yang sudah membantu penelitian ini sehingga bisa berjalan dengan baik khususnya Rumah Sakit Umum Daerah Wangaya.

\section{DAFTAR PUSTAKA}

Mansjoer Arif, Suprohaita, Wardani, Setiowulan, Wicaksono A, Hamsah, Rukmawati A, Anggraini D, Patmini E, Suartana, Patria F,
Rinaldi I, Harimurti, Triyanti K, Busroh WP, Savitri, Febrianto R, Hudaya S, Anindhita T, Dwiyandari V, Wendyanyah, Dewi FW, 2000, Kapita Selecta Kedokteran, Edisi III jilid 2, Media Aesculapius FKUL, Jakarta, 432

Ria Etikasari, Tri Murti Andayani, Ali Gufron Mukti 2012. Analisis Biaya Dan Kesesuaian Penggunaan Antibiotika Pada Demam Tifoid Di Rsud Kota Yogyakarta, Universitas Gadjah Mada.

Rima Fitriani Susono, Sudarso, Githa Fungie Galistiani, 2014. Cost Effectiveness Analysis Pengobatan Pasien Demam Tifoid Pediatrik Menggunakan Cefotaxime dan Chloramfenikol di Instalasi Rawat Inap RSUD Prof. DR. Margono Soekarjo. Fakultas Farmasi Universitas Muhamadiyah Purwokerto.

Trask, S.L., 2011, Pharmacoeconomics: principles, methods, and applications, The McGrawHill Companies.

Vogenberg, F. R. 2001. Introduction to Applide Pharmacoeconomics. McGraw Hill Medical Publishing Division, USA Alimul, Aziz. 2005. Pengantar Ilmu keperawatan anak. Jakarta: Salemba Medika. 